\title{
Effect of stirrup type on shear capacity of reinforced concrete members with circular cross section
}

\author{
Sri Hartati Dewi ${ }^{1, *}$, Rendy Thamrin ${ }^{2}$, Zaidir $^{2}$, and Taufik ${ }^{3}$ \\ ${ }^{1}$ Civil Engineering Department, Engineering Faculty, Islamic University of Riau, 28284, Pekanbaru, Indonesia \\ ${ }^{1}$ Doctoral Student, Civil Engineering Department, Andalas University, 25163, Padang, Indonesia \\ ${ }^{2}$ Civil Engineering Department, Engineering Faculty, Andalas University, 25163, Padang, Indonesia \\ ${ }^{3}$ Civil Engineering Department, Engineering Faculty, Bung Hatta University, Padang, Indonesia \\ ${ }^{3}$ Doctoral Student, Civil Engineering Department, Andalas University, 25163, Padang, Indonesia
}

\begin{abstract}
An experimental study of shear behaviour of reinforced concrete members with solid circular cross sections is presented. The test variables were ratio of longitudinal reinforcement and type of stirrups. The test was carried out on nine beams. Three beams were designed without stirrups, three with closed hoop stirrups, and the other with spiral stirrups. All tested beams were subjected to two-point monotonic loads. The test results showed that all beams without stirrups failed due to the shear force. Beams with hoop or spiral stirrups failed in flexural mode. The flexural capacity of beams with hoops and spiral stirrups was similar but the beams with spiral stirrups showed a slightly higher ductility. Analytical predictions showed that the chosen numerical model predicted the test result with good accuracy.
\end{abstract}

\section{Introduction}

Up until December 14, 2018- before the tsunami disaster in the Selat Sunda, Badan Nasional Penanggulangan Bencana (BNPB) had recorded 2,436 natural disasters in Indonesia [1]. In general, the number of disasters has been trending upward over the past decade. The most frequently occurring are floods, landslides and tornadoes. However, the risks from earthquakes and tsunamis are also relatively high.

Natural disasters, especially earthquakes, are usually unpredictable but the risks from earthquakes can be minimized. One way to do this is to use disaster mitigation planning in building new structures [2]. Experience of previous earthquakes in Indonesia has shown that buildings frequently fail due to damage in the beams and columns of the structure. Damage to beams is exacerbated by lack of stirrups, damage to columns is exacerbated by the lack of reinforcement.

Most of the research on reinforcement of concrete members is focused on rectangular cross sections [3]. However, circular cross sectional reinforced concrete elements are frequently used civil engineering construction, for instance, as columns in reinforced concrete buildings, as pile foundations, and bridge piers [4-5]. The circular shaped cross section allows structural elements to have the same response to internal forces that occur from all directions [6]. The shear capacity of circular cross sectional reinforced concrete elements is different from other cross sections. The circular cross sectional shear capacity of reinforced concrete structural elements has been investigated by several previous researchers before [3-12]. Thamrin et al. [3] has developed an analytical prediction model that has been found to compare well with experimental results. Jensen et al. [4] used experimental results of the shear forces on rectangular elements to predict the shear forces on circular cross section elements. Turmo et al. [5] developed an analogy for shear in circular concrete truss elements with hollow and solid cross-section. Feltham [8] proposed that more values of shear reinforcement must be investigated to determine the shear resistance provided by spiral stirrups. This study builds on and develops this research by investigating the shear experienced by circular cross-sectional beams.

\section{Experimental Study}

There were nine beams in this test. Three beams were designed without stirrups (CB0), three with closed hoops (CSC), and the others with spiral stirrups (CSS). The diameter of stirrups used was $10 \mathrm{~mm}$. The strength of compressive concrete was $20.1 \mathrm{MPa}$ ordered from a ready-mix concrete company. Threaded reinforcing steel was used as longitudinal reinforcement with $13 \mathrm{~mm}, 16$ $\mathrm{mm}$ or $19 \mathrm{~mm}$ diameters. The average modulus of elasticity of the steel was $200 \mathrm{GPa}$. The values of yield stress of each type of reinforcement were $340 \mathrm{MPa}, 420$ $\mathrm{MPa}$, and $386 \mathrm{MPa}$ respecively. The load applied through the hydraulic pump and deflection that occurs at the point load and middle positions were measured by a load cell and Linear Variable Differential Transformer (LVDT) which was connected to the data acquisition

\footnotetext{
${ }^{*}$ Corresponding author: srihartatidewi@eng.uir.ac.id
} 
system.
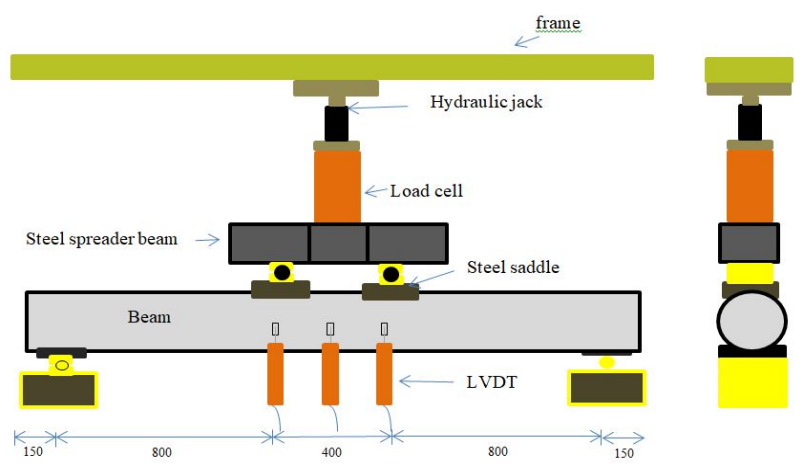

Fig.1 Set up of experiment and equipment used.

Figure. 2 shows the loading position, dimensions and cross-section of the beam.

(a)

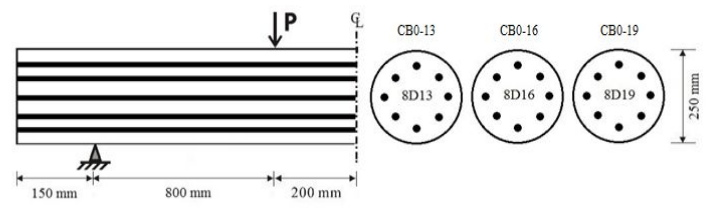

(b)

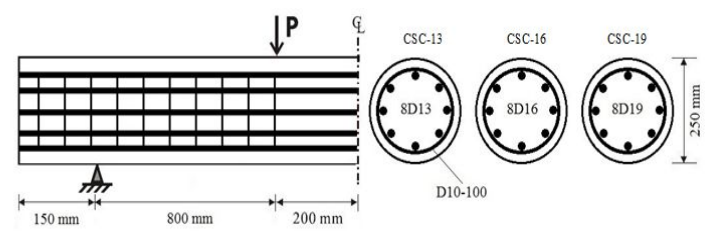

(c)

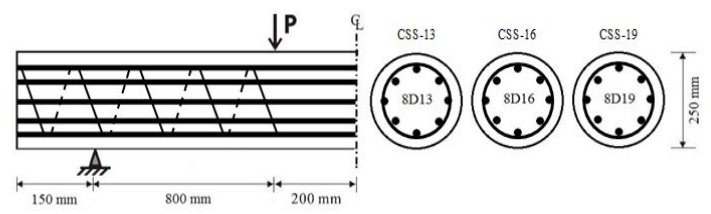

Fig.2 Types of beam (a) without stirrups (CB0); (b) with closed circular stirrups (CSC); (c) with circular spiral stirrups (CSS)

\section{Analytical Study}

The theory of moment-curvature determination is the basis of the numerical model used [8]. The cross-section of reinforced concrete can be divided into a number of concrete and reinforcement layers as shown in Fig. 3. The stress-strain relationship of concrete in compression was applied [10]. The first crack in the cross-section was the basis for the calculation of the tensile stress of the concrete. The stress-strain relationship for the concrete was assumed to be linear to tensile strength with no consideration of the effect of tension stiffening. A linear stress-strain relationship for steel was assumed.

The internal force balance in cross section was obtained and the load-deflection curve calculated from the moment-curvature relation.

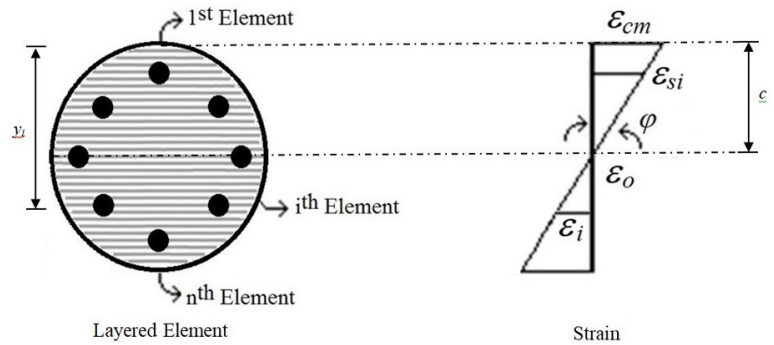

Fig.3 Layered elements in cross section and distribution of strain

The application of this method uses Reinforced Concrete Cross Section Analysis (RCCSA) software [11]. The capacity of the cross section of beams, slabs, and columns can be calculated from RCCSA. The full response of the cross section due to monotonic and cyclic loads can be obtained from these software models by moment-curvature calculations. A screenshot of the RCCSA interface is shown in Fig.4.

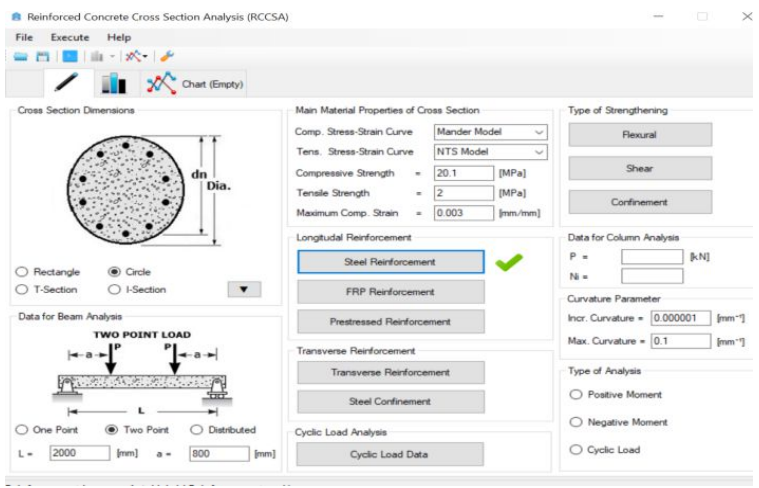

Fig. 4. A screenshot of the RCCSA interface

Theoretical values for the specimens used were selected from existing equations for nominal shear strength $\left(V_{n}\right)$ provided by ACI 318M-14 [12]:

$$
\begin{aligned}
& V_{n}=V_{c}+V_{s} \\
& V_{c}=0.17 \lambda \sqrt{ } f_{c}^{\prime} b_{w} d \\
& V s=A_{s} f_{y} d / s
\end{aligned}
$$

Where $\mathrm{V}_{\mathrm{c}}$ is shear strength of concrete (eq.2) and $\mathrm{V}_{\mathrm{s}}$ is shear strength of reinforcement (Eq.3).

\section{Test Results and discussions}

Obvious flexural and shear cracks could be observed in the beams at failure. The crack pattern and the failure mode of the beam without stirrups are shown in Figure.5.

Generally, the beams without stirrup have shear failure with several diagonal cracks. Shear failure due to shear crack propagation up to the point of load and down to the zone near the point of support. 


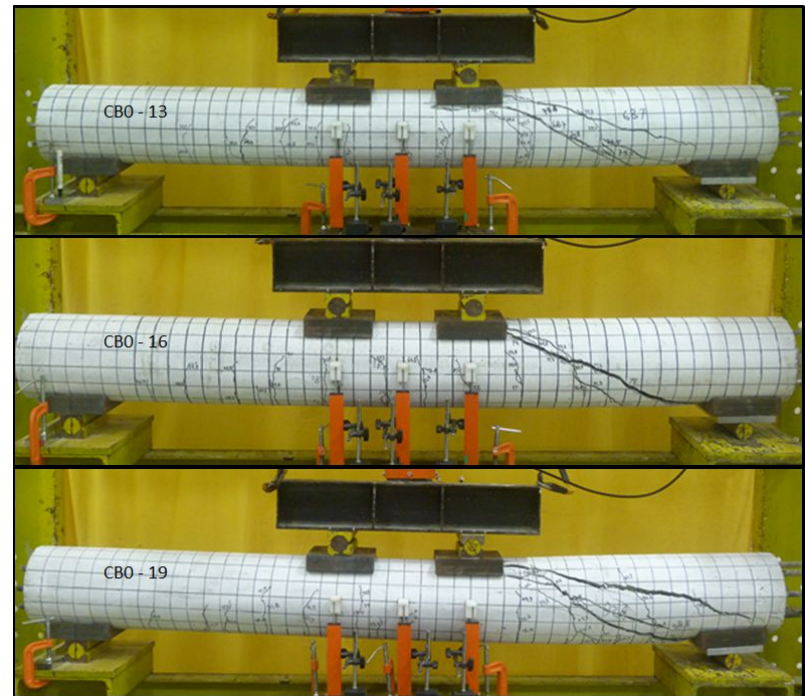

Fig.5 Crack patterns of beams without stirrups

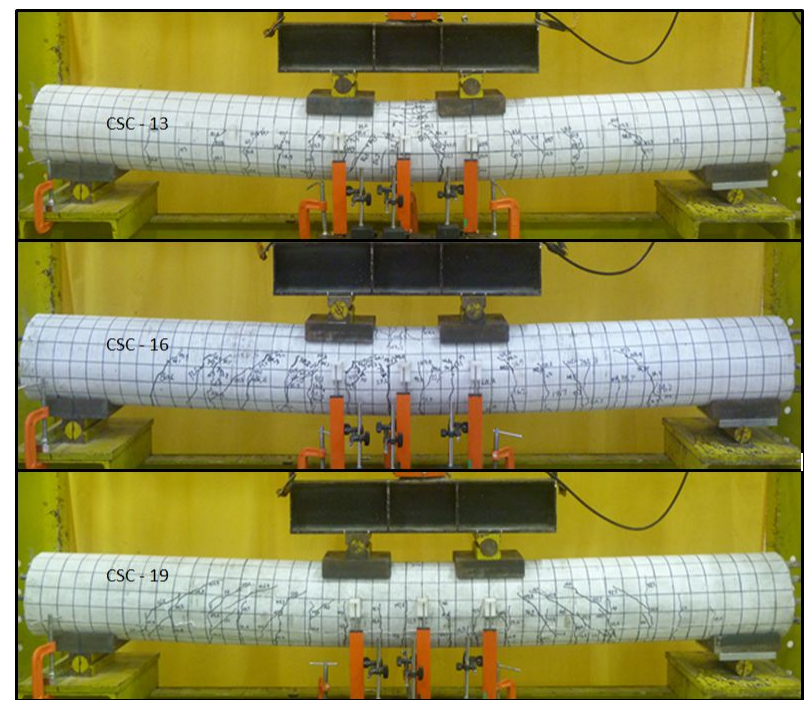

Fig.6 Crack patterns of beams with closed circular stirrups (type I)

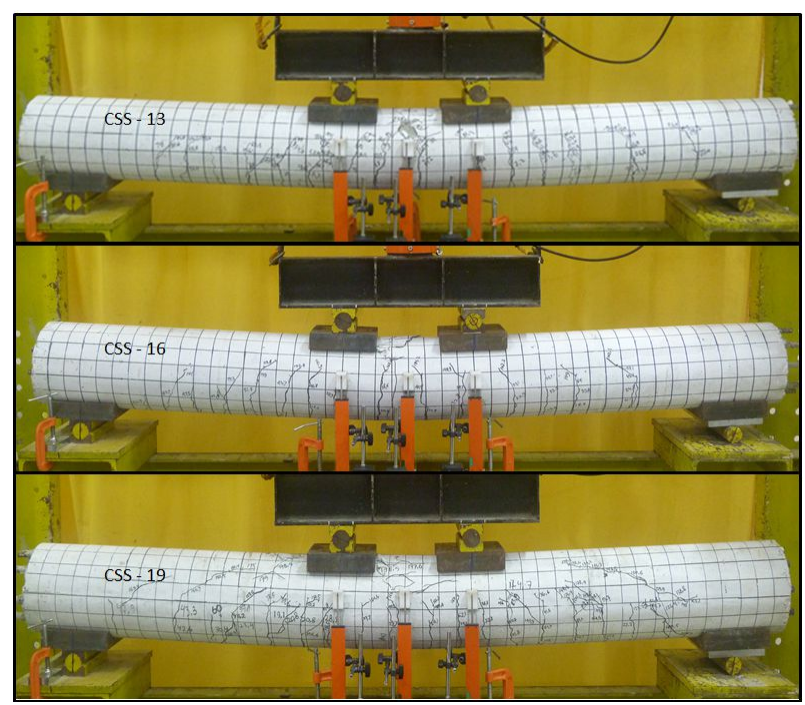

Fig.7 Crack patterns of beams with circular spiral (Type II)

The beams with closed hoop stirrups are shown in Fig. 6 and beams with circular spiral stirrups shown in
Fig.7. Results indicated that the concrete has been crushed at the top of the concrete compression zone. The cracks in failure mode are similar being distributed along the beam tension zone which is dominated by flexural cracks.

Fig.8 shows the load-deflection capacities of beams. The deflection value data was obtained from the displacement transducer in the middle range of the beam. Fig.8 (a) shows the load-deflection curves of beams without stirrups (CB0-13, CB0-16, and $\mathrm{CB} 0-19)$ which suddenly collapse due to shear failure.

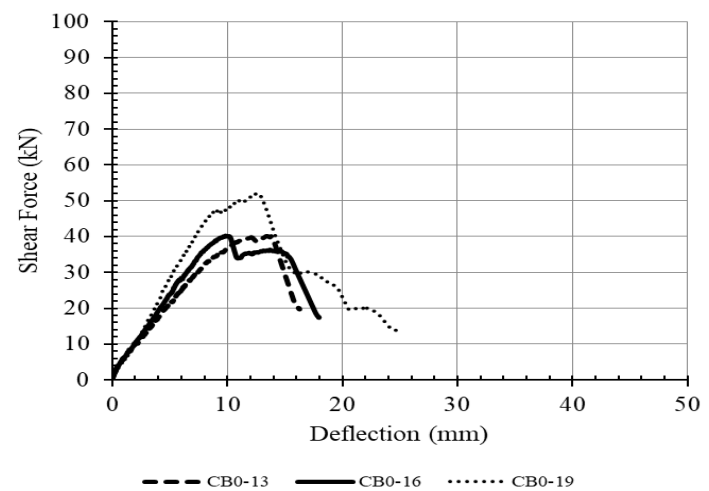

(a). Beams without stirrups

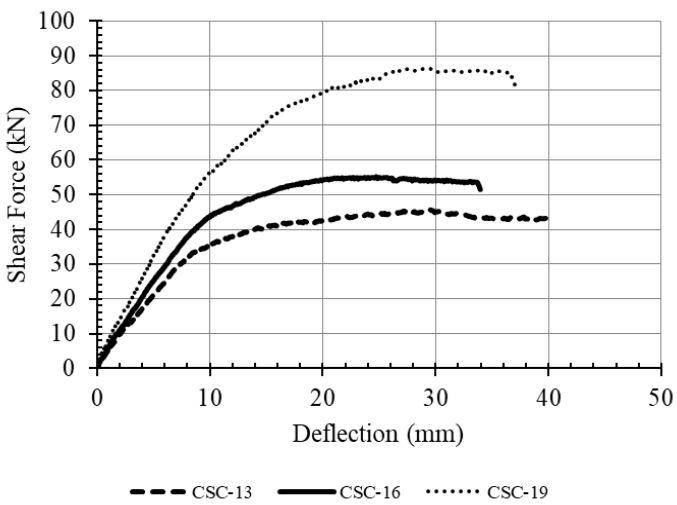

(b). Beams with closed circular hoop stirrups

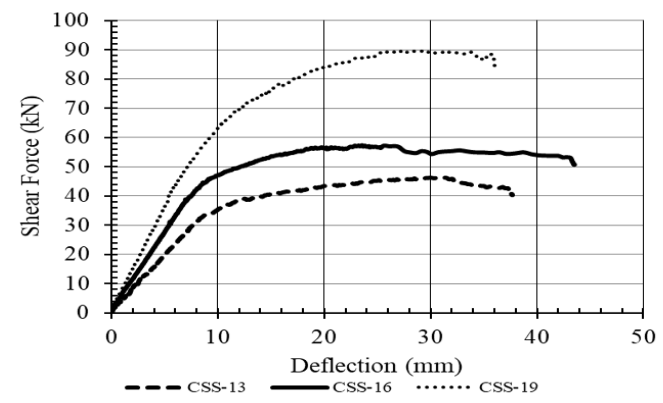

(c). Beams with circular spiral stirrups

Fig.8. Load-deflection graph of each type of stirrup

Figure 8(b) and Figure 8(c) show the similarity of the flexural capacity of the beams with closed hoops and those with spiral stirrups. Beams with spiral stirrups show slightly higher ductility. 
Figure.9, shows shear capacities of each type of stirrup with the same longitudinal reinforcement ratio, along with the analytical predictions from the model. Figure 9(a), 9(b), and 9(c) show shear capacity of the beam with $13 \mathrm{~mm}, 16 \mathrm{~mm}$ and $19 \mathrm{~mm}$ diameter longitudinal reinforcement. The beams without stirrups (CB0-13, CB0-16, and CB0-19) suddenly collapsed due to shear failure. The beams using close hoops stirrups (CSC-13, CSC-16 and CSC-19) and spiral stirrups (CSS13, CSS-16 and CSS-19) had high shear capacity and deflection.

There was no significant difference in response between similarly reinforced elements with closed hoop or spiral stirrups. The numerical model was found to predict the test result with a high level of accuracy.

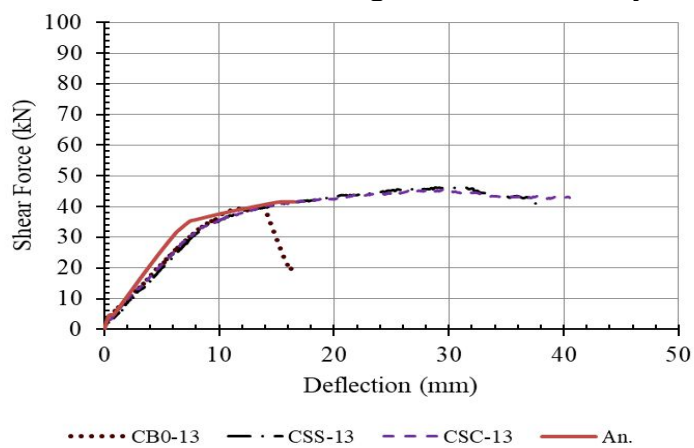

(a). $13 \mathrm{~mm}$ diameter beams

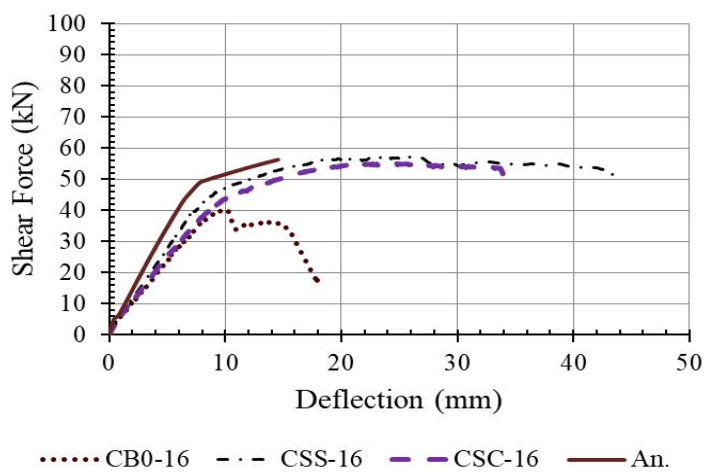

(b). $16 \mathrm{~mm}$ diameter beams

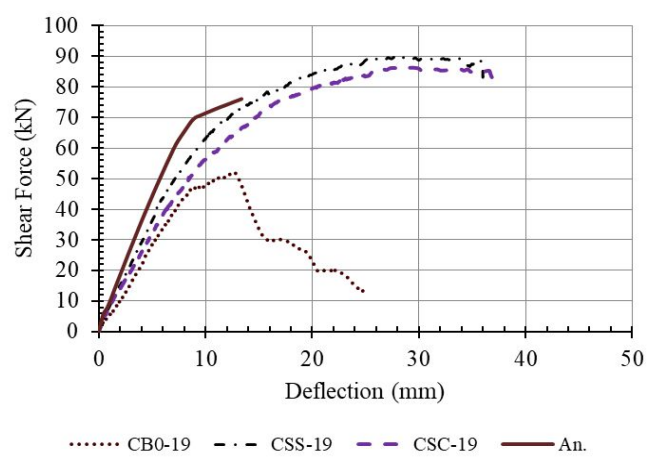

(c). $19 \mathrm{~mm}$ diameter beams

Fig. 9 Load-deflection graph of each specimen with the same longitudinal reinforcement ratio comparison with analytical prediction

\section{Conclusion}

Nine simply supported reinforced concrete beams. Three beams were designed without stirrups (CB0), three beams with closed hoops (CSC), and the other with spiral stirrups (CSS). The following conclusions were drawn:

a. The modes of failure of the beams observed from the test were flexural and shear.

b. Failure of beams without stirrups was caused by diagonal shear cracks developed in the shear span zone.

c. Flexural capacities of beams with hoop and spiral stirrups were nearly similar, but the beams with spiral stirrups showed a slightly higher ductility.

d. Analytical prediction showed that the numerical model predicts the experimental result with good accuracy.

e. These results underline the importance of the use of stirrups in circular cross sectional members when building in an area that is prone to shear forces such as those experienced from earthquake

\section{References}

1. https://www.liputan6.com/news/read/3859198/bmkgaktivitas-gempa-di-indonesia-meningkat-drastis-ditahun-2018

2. H. Priyosulistyo, Mitigasi Bencana Gempa Bumi Pada Bangunan Gedung dan Jembatan- Suatu Upaya Mencegah Korban Jiwa, (2010)

3. R. Thamrin, R. Kurniawan, A. P. Melinda, Procedia Engineering 171 957-964, (2017)

4. U. G. Jensen, L. C. Hoang, H. B. Joergensen, L. S. Fabrin, Eng Struct 32(3) 617-626, (2010)

5. Turmo J, Ramos G, Aparicio AC, Engg Struct 31(2): 455-465 (2009)

6. Y. L. Wong, T. Paulay, M. J. N. Priestley, ACI Structural J. 90(2) 180-191, (1993)

7. J. L. Clarke, F. K. Birjandi, Struct Engg 71(5)73-78, (1993)

8. I. Feltham, Struct Engg, 84(11) 27-31, (2004)

9. R. Park, T. Paulay, Reinforced Concrete Structures John Wiley, New York, (1975)

10. Mander, J. B., Priestley, M. J. N., and Park, R, J Struct, Engg (ASCE) 114(8) (1988) 1804-1826

11. Thamrin, R., Reinforced Concrete Cross Section Analysis (RCCSA) V4.3, Jurusan Teknik Sipil, Fakultas Teknik, Universitas Andalas (2014)

12. American Concrete Institute (ACI), Buildibg Code Requarements for Structural Concrete (ACI 318-14) and Commentary (ACI 318R-14), Farmington Hills, MI (2014) 